ERJ

Engineering Research Journal

Faculty of Engineering

Menoufia University

\title{
Monorail System as Urban Sustainable Transit in Alexandria
}

\author{
El Adawy, Amr M.*
}

\author{
(*Correspondent: Eng. Amr M. El Adawy, Teaching Assistant and MSc Candidate, Architectural \\ Engineering and Environmental Planning Department, Arab Academy for Science and Technology \\ and Maritime Transport, amr-el-adawy@hotmail.com)
}

\begin{abstract}
Alexandria city is the second largest and second most populated city in Egypt. It suffers from high levels of congestion and air pollution. In order to reverse this decline in the quality of life in cities, attempts should be encouraging people to reduce the usage of private cars and impress the usage of different public transportation. Taking in consideration that existing public transportation mode choices are unsustainable and undeveloped mode. Hence, the Governments must seek for sustainable modes of public transport, which make use of the road space more efficiently than private transport. The aim of the paper is to provide a study of Urban Monorail System (UMS) as a successful tool that is used all over the world to improve the urban development, activities and the overall urban environment. The paper method is Qualitative. Finally, the researcher sets out a Transport Questionnaire directed to the users of the recent transit mode under study concluding with recommendations that reflect their needs and points of view which can be implemented in the current policies governing Alexandria for the future.
\end{abstract}

Keywords: Sustainable Public Transport System, Monorail Transit, Heavy Rail Transit, Transport Questionnaire

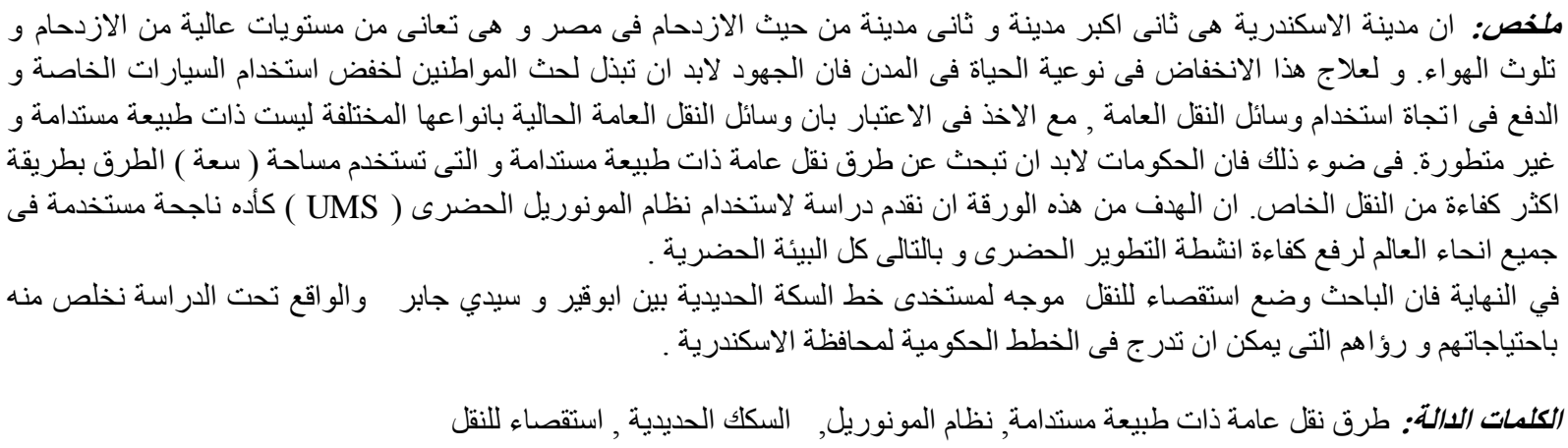

\section{Introduction}

In Alexandria at present, people's car uses are more private, which leads to more cars on the road, heavy traffic congestion and air pollution. To solve this problem, people must be encouraged to use Urban Public Transport, which is introduced in easy and reliable service.

Using Urban Public Transport have many advantages, which can be summarised as follows in Table 1.1: 
Table 1.1: Advantages of Urban Public Transport

\begin{tabular}{|c|c|}
\hline & Advantages \\
\hline Social & $\begin{array}{l}\text {-It helps promote a sense of } \\
\text { community. For example, } \\
\text { people who are travelling } \\
\text { together are more likely to } \\
\text { feel the connected } \\
\text { community of those who } \\
\text { travel in cars in isolation. } \\
\text {-People are encouraged to } \\
\text { lifestyle healthier activity, } \\
\text { especially if they are walking } \\
\text { or cycling to the station or } \\
\text { stop. } \\
\text {-It helps reduce injuries and } \\
\text { deaths from car accidents. } \\
\text {-Availability of } \\
\text { transportation to get to } \\
\text { people regardless of } \\
\text { demographics such as } \\
\text { income or age. } \\
\text {-It is less stressful. Instead of } \\
\text { driving in traffic or wasting } \\
\text { time searching for the elusive } \\
\text { car park, passengers can } \\
\text { public transport to relax and } \\
\text { listen to music or read a } \\
\text { book. }\end{array}$ \\
\hline Economic & $\begin{array}{l}\text {-Travel is cheaper than } \\
\text { owning and operating a car. } \\
\text {-It reduces the need for the } \\
\text { construction of car parks on } \\
\text { valuable land that could } \\
\text { otherwise be used as an } \\
\text { office of great value or retail } \\
\text { space. } \\
\text {-Reduces dependence on } \\
\text { rapidly diminishing oil } \\
\text { supplies. }\end{array}$ \\
\hline Environmental & $\begin{array}{l}\text {-Reduce pollution and } \\
\text { congestion on the roads. } \\
\text {-It requires less land use of } \\
\text { road infrastructure. }\end{array}$ \\
\hline
\end{tabular}

All of these advantages will reflect on the reduction of traffic congestion and wasting of time whenever Public Transport is developed to be faster and convenient for citizens.

(UNITED NATIONS, BUREAU INTERNATIONAL DES EXPOSITIONS, \& CITY OF SHANGHAI, 2010) (Public Transport Victoria, 2013)

\section{Unsustainable Urban Public Transport Systems}

The diversity of unsustainable and undeveloped mode choices of Urban Public Transport in Alexandria (Figure 2.1) is a major problem and there is a demand to be developed to achieve a sustainable system.
Each current unsustainable public transit mode in Alexandria has its problems, such as:

- Public Bus: it needs a large number of labours for operation, causing pollution, causing street congestion, it is a slow service, having a low capacity and is not comfortable transit mode.

- Light Rail (Tram System) and Heavy Rail (Commuter Railway System): They need huge investments, high cost for maintenance, high cost for salaries to be paid, government monopolised, lacks door -to- door service, less coverage and it interferes with street traffic.
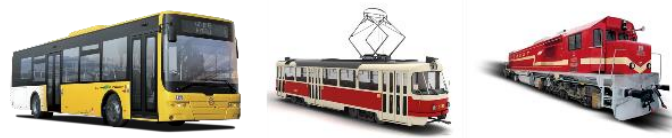

Figure 2.1: The diversity of unsustainable and undeveloped mode choices of transportation: Public Bus, Light and Heavy Rail System. (Ahkâm, 2016) (Tram, 2016) (www.waterkingdom.in)

The paper focuses on the line of Heavy Rail (Commuter Railway System) in Alexandria. Heavy Rail (Commuter Railway System) considers as the fastest Urban Transport in Alexandria.

Using Heavy Rail (Commuter Railway System) has many reasons to exercise caution in Alexandria, which can be summarised in the downward table (Table 2.1):

Table 2.1: Heavy Rail's reasons to exercise caution

\begin{tabular}{|c|c|}
\hline \multicolumn{2}{|r|}{ Caution } \\
\hline $\begin{array}{c}\text { Huge } \\
\text { investment }\end{array}$ & $\begin{array}{l}\text { The railways require a huge } \\
\text { investment. This is because the cost } \\
\text { of a train is many times higher than } \\
\text { that of a road vehicle. Also, the } \\
\text { construction of the tracks involves a } \\
\text { lot of money. }\end{array}$ \\
\hline Cost & $\begin{array}{l}\text { The railways have to incur high } \\
\text { overhead costs. This is because of } \\
\text { maintenance of trains and tracks. } \\
\text { Also, the salaries paid to the } \\
\text { technical and another staff is quite } \\
\text { high as compared to the salaries of } \\
\text { road drivers and others. }\end{array}$ \\
\hline $\begin{array}{l}\text { Government } \\
\text { monopoly }\end{array}$ & $\begin{array}{l}\text { Railways are operated and managed } \\
\text { by the government. At times, the } \\
\text { railway authorities are negligent in } \\
\text { their duties. They also do not } \\
\text { provide personalised services. }\end{array}$ \\
\hline $\begin{array}{c}\text { Lacks door- } \\
\text { to-door } \\
\text { service }\end{array}$ & $\begin{array}{l}\text { Railways cannot provide door-to- } \\
\text { door service. The rail service is } \\
\text { available along the railway routes } \\
\text { only. It is only the Road Transport } \\
\text { that can provide door-to-door } \\
\text { service. }\end{array}$ \\
\hline Less coverage & $\begin{array}{l}\text { The railways operate partly in an } \\
\text { urban area, because of high costs. }\end{array}$ \\
\hline
\end{tabular}

(Lynn) ( Erdemir) 


\section{Urban Monorail System (UMS) as} Sustainable Urban Public Transport System

\subsection{Sustainable Urban Public Transport System}

'Sustainable transportation is the maintenance of mobility and accessibility at some socially predetermined level and perhaps subject to selected social and environmental constraints, for example, maintaining predetermined levels of environmental residuals'. (Rietveld \& Stough, 2010)

This definition has other aspects to meet the basic needs of people and communities, as well as justice in every generation, and between generations. Sustainable transport means following a model that despite the population growth, the city, and the development and growth of its economy and social and other community activities is suitable to transport passengers without causing a traffic problem. This model has demanded the growth of the community and human activity management because it is still efficient and sustainable.

( Joodi, Momeni, Kooshki, \& Azizi, 2011) (Black, 2010) ( Desmond, 2015)

\subsection{UMS}

The monorail is a railway system in which the track consists of a single rail, typically elevated and with the trains suspended from it. The term is also used to describe the beam of the system, or the vehicles travelling on such a beam or track. UMS have been built in many countries around the world, many of them on elevated tracks through crowded areas that would otherwise require the construction of expensive underground lines or have the disadvantages of surface lines. UMS stations have been the urban nodes of the city with activities and land uses.

( Wang, 2003) (Kennedy, Considering Monorail Rapid Transit for North American Cities) (Tarighi, 2011)

There are 2 Types:

- Suspended Urban Monorail

- Straddle Urban Monorail

This paper will focus on Straddle Monorail.

\subsubsection{Straddle UMS}

The most common monorail type is the straddle monorail, that has been put into operation. It is the most visually pleasing type and fits into urban environments better than suspended monorails. It is composed of a train running on a concrete or steel guideway. The train's load bearing tires run on top of the guideway beam while the guidance tires run along the two sides of the said beam.
(Kennedy, Considering Monorail Rapid Transit for North American Cities) (Japan Monorail Association Guide) (Tarighi, 2011) (Kuwabara, et al., 2001) (Ishikawa, Ohazama, Sora, \& Sekitani, 1999)

(Figure 3.1)

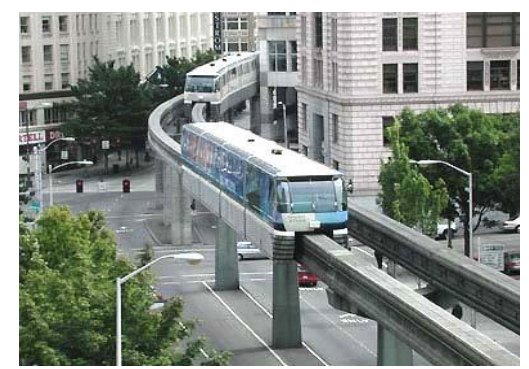

Figure 3.1: Seattle Alweg Monorail, Straddle Monorail (1962). Source: (Kennedy, Considering Monorail Rapid Transit for North American Cities)

\subsubsection{Advantages and Disadvantages of UMS}

(Table 3.1)

Table 3.1: Advantages and Disadvantages of UMS

\begin{tabular}{|c|c|}
\hline \multicolumn{2}{|r|}{ Advantages } \\
\hline $\begin{array}{l}\text { Monorails are } \\
\text { nonpolluting, } \\
\text { quiet, and } \\
\text { automated }\end{array}$ & $\begin{array}{l}\text { All these characteristics are } \\
\text { approximately the same for } \\
\text { any electrically powered } \\
\text { modern transport system on a } \\
\text { guide- way or rails. }\end{array}$ \\
\hline Safety & $\begin{array}{l}\text { - The record has been } \\
\text { extremely good, with serious } \\
\text { operational accidents not yet } \\
\text { encountered. } \\
\text { - Personal safety has also } \\
\text { been exceptional, and } \\
\text { systems operate in } \\
\text { controlled environments, } \\
\text { and extensive surveillance } \\
\text { programs done by monitors } \\
\text { and safety personnel are in } \\
\text { place. }\end{array}$ \\
\hline $\begin{array}{l}\text { Suitability for } \\
\text { constrained } \\
\text { spaces }\end{array}$ & $\begin{array}{l}\text { - All the dimensions of UMS } \\
\text { elements are measurably } \\
\text { smaller than those of } \\
\text { conventional transit. } \\
\text { - Little noise or vibration is } \\
\text { generated. } \\
\text { - Placed in a separate path, so } \\
\text { there is no interference with } \\
\text { traffic on already overloaded } \\
\text { surface streets. } \\
\text { - There are better } \\
\text { opportunities to thread lines } \\
\text { through intensely developed } \\
\text { districts, and even buildings } \\
\text { can be penetrated. }\end{array}$ \\
\hline
\end{tabular}




\begin{tabular}{|c|c|}
\hline $\begin{array}{l}\text { Vehicles are not } \\
\text { likely to derail }\end{array}$ & $\begin{array}{l}\text { - It is practically impossible } \\
\text { for the vehicle to leave the } \\
\text { beam or channel, although } \\
\text { other mechanical problems } \\
\text { are not precluded. } \\
\text { - Suspended monorails claim } \\
\text { to be weatherproof because } \\
\text { rain and snow cannot enter } \\
\text { the guideway channel. }\end{array}$ \\
\hline $\begin{array}{l}\text { Low labour } \\
\text { input }\end{array}$ & $\begin{array}{l}\text { Since there are no drivers or } \\
\text { conductors on the vehicles and } \\
\text { passengers may not see any } \\
\text { employee of the operating } \\
\text { agency, there are considerable } \\
\text { savings on the personnel side } \\
\text { of the ledger. }\end{array}$ \\
\hline $\begin{array}{l}\text { Advanced } \\
\text { technology } \\
\text { image }\end{array}$ & $\begin{array}{l}\text { - Monorails are associated in } \\
\text { the public mind with } \\
\text { technological advancement } \\
\text { and visionary concepts. } \\
\text { - This may be a considerable } \\
\text { positive force, possibly } \\
\text { generating considerable } \\
\text { public and civic support for } \\
\text { implementation. }\end{array}$ \\
\hline \multicolumn{2}{|r|}{ Disadvantages } \\
\hline $\begin{array}{l}\text { Switching is } \\
\text { cumbersome }\end{array}$ & $\begin{array}{l}\text { While vehicles can certainly } \\
\text { be switched from one line to } \\
\text { another, an entire section of } \\
\text { the supporting beam has to be } \\
\text { moved to accomplish each } \\
\text { manoeuvre. }\end{array}$ \\
\hline $\begin{array}{l}\text { Fragility of } \\
\text { system }\end{array}$ & $\begin{array}{l}\text { Automated types of monorails } \\
\text { are characterised by highly } \\
\text { advanced technology with } \\
\text { components that can be } \\
\text { somewhat delicate. }\end{array}$ \\
\hline $\begin{array}{c}\text { Monorails can } \\
\text { only operate in } \\
\text { an elevated } \\
\text { configuration }\end{array}$ & $\begin{array}{l}\text { The lines can't be placed on } \\
\text { the surface because cross } \\
\text { traffic can't be accommodated } \\
\text { on the same level. }\end{array}$ \\
\hline $\begin{array}{l}\text { The vehicles are } \\
\text { more expensive }\end{array}$ & $\begin{array}{l}\text { The suspension or straddling } \\
\text { mechanisms are more complex } \\
\text { than regular bodies or truck } \\
\text { sunder standard rail cars }\end{array}$ \\
\hline
\end{tabular}

\begin{tabular}{|c|l|}
\hline $\begin{array}{c}\text { Evacuation of a } \\
\text { stalled or } \\
\text { disabled train is } \\
\text { a problem }\end{array}$ & \begin{tabular}{l} 
(while the passenger \\
compartments can be identical \\
to those of any other rail car). \\
channel does not provide for \\
any walkway, the safe \\
accommodation of passengers \\
along the elevated structure \\
under emergency conditions \\
will require special \\
arrangements and catwalks. \\
\hline Cost factors \\
Capital investments will be \\
considerable because a \\
completely new exclusive \\
guideway has to be created. \\
Advanced technology \\
vehicles have to be acquired, \\
and sophisticated \\
maintenance facilities have \\
to be made available which \\
are considerably expensive.
\end{tabular} \\
\hline
\end{tabular}

(Grava, 2004) (Monorails For Public Transit Pros $\&$ Cons, 2009) (Green) (The Pros and Cons of the Monorail Pub Crawl, 2014) (He, 2015) (Japan Monorail Association Guide) (Hitachi, 2013)

\subsubsection{UMS Stations}

They are the major nodes placed on the railway tracks, acting as starting and ending points for the rail trips. Stations are like external magnets to projects and internal commercial centres with shops and hotels. The station no longer acts as a travel alone building, but it is an independent space with retail, social and cultural facilities (Edwards, 1997).

Stations consist of four main elements:

- The main station concourse, where passengers, visitors and shoppers gather together.

- The platform, where passengers enter or leave the trains.

- The offices, stores, maintenance yards and tracks.

- The transition Plaza, which is the place that is responsible for passenger gatherings and for the movement from parking areas or modal access to the station.

(Edwards, 1997) (RailnetEurope, 2013) 


\section{Case Study: Alexandria's Internal Urban Commuter Railway System}

Internal Urban Commuter Railway System (IUCRS) in Alexandria travels along Alexandria passing through stations. Each station is acting as Urban Nodes for the district it exists along the rail.

(Figure 4.1)

Abuqir Railway Stations:

1. Abuqir Station

2. Tosson Station

3. El Maamoura Station

4. El Eslaah Station

5. El Montazah Station

6. El Mandara Station

7. El Asafra Station

8. Sidi Beshr Station

9. Victoria Station

10. El Raml El Amiri Station

11. Ghubrial Station

12. Bakous Station

13. El Dahreya Station

14. Sidi Gaber Station

15. El Hadara Station

16. Mhatet Masr Station

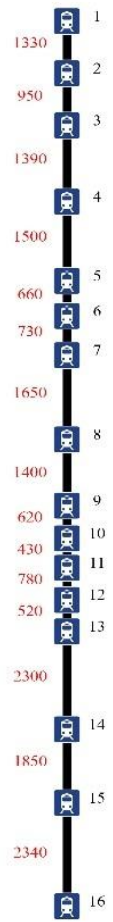

Figure 4.1:

Abuqir Railway Stations

The case study starts from Abuqir Station till Sidi Gaber Station.

\subsection{SWOT Analysis \\ 4.1.1 Strength}

Social Analysis:

The presence of social interaction among people from different levels.

\section{Accessibility and Traffic:}

- Railways infrastructure is already built.

- Railways network connects the Middle and Eastern parts of Alexandria.

Environmental Analysis:

- The moderate temperature throughout the year and sea breeze.

- In winter, the temperature is not too low.

Site Analysis:

There are a lot of landmarks and places in Alexandria.

\subsubsection{Weakness}

Social Analysis:

- The imbalance between the number of passengers with the number of IUCRS cars at rush-hour congestion.

- Lack of social awareness and presence of street vendors in the IUCRS cars.

Accessibility and Traffic:

- The IUCRS stations are not accessible for all neighbourhoods' people along Alexandria.

- No sidewalks or bridges that lead to IUCRS stations.

- Lack of safety due to the overcrowding platforms since arrival IUCRS cars.

Environmental Analysis:

- No maintenance for shades and benches for passengers at IUCRS stations.

- Reduce of air quality and the amount of oxygen needed by every passenger due to the rush-hours.

- Lack of acoustics preservation from IUCRS cars.

Site Analysis:

- There are not paths leads to IUCRS stations.

- Lack of coordination among neighbourhoods' land uses.

\subsubsection{Opportunities}

Social Analysis:

- Spreading awareness among people to decrease social problems and crimes.

- Community engagement in development and rehabilitation services and maintained railway cars and stations to serve the people.

Accessibility and Traffic:

- Making the stations accessible from all directions for people and provide walking paths and bridges.

- Depending on the railways as main mean of transportation to decrease of usage of cars and traffic jams.

Environmental Analysis:

- The presence of shades and benches for passengers.

- Combine the infrastructure with natural functions.

- Use Green Buffer Zone to prevent the dust carried by winds and to increase air quality.

Site Analysis:

- Preservation of shades and benches for passengers.

- Provide the stations with services and public toilets.

- Adaptive reuse of buildings which are in good condition.

- The increase of mixed use buildings. 


\subsubsection{Threats}

Social Analysis:

- Poverty and unemployment lead to major crimes.

- Overcrowding in IUCRS cars leads to social problems and sexual harassments.

Accessibility and Traffic:

- The absence of safety for the passengers.

- Delay of IUCRS trains leads to rushing people to it causing a lot of accidents.

- Social problems and sexual harassments.

Environmental Analysis:

- Spreading of diseases due to low air quality.

- Rain falls may cause drainage problems because of the bad infrastructure of the stations and along railway path.

Site Analysis:

- Missing of mixed uses may encourage crime and illegal actions at night.

- Buildings of the stations may collapse over time if the remained unpreserved.

- Buildings with illegal heights might become more common.

\subsection{Proposal}

Implementation of the Urban Monorail System will promote better urban development along the path of urban transit in Alexandria. It will be an initial step for sustainable urban transportation in Alexandria, after which the rest modes of transit will be developed in the future to be sustainable.

The proposal includes also the keeping of the recent IUCRS beside the new UMS as a support till the finish of implementation of the UMS and its stable operation as mentioned Figure 4.4.

Impacts of UMS on Urban Planning:

\section{$>$ Reducing Traffic Congestion}

- Increasing Accessibility: It will be reflected on the access to residential, business activities, educational facilities and city centre which are always overcrowded.

- Integration with other modes of transit Impact: Ease the achievement of Door-to-door Service.

\section{$>$ Revitalization and Region's Development}

It will help to create an integrated regions including:

- Commercial investments and business centres to overcome the phenomena of a peddler and Random Markets.

- Garages for private cars to serve public passengers.

- Bus/taxi hubs to serve public passengers.

\section{Road and Streetscape Enhancements}

Through organising streets into lanes each serving Buses, cars, motorcycles, bikes and pedestrians. Enhancing streetscape through the implementation of light units, shelters and seating units, etc.

\section{UMS and City Urban Expansion}

According to the expansion of the city, it is a must to settle the principle of Smart Growth of the UMS line to be spread over the whole city and its suburbs.

\section{UMS Environmental and Health Benefits}

It will be reflected on:

- Reduction of construction material consumption and energy consumption.

- Reduction of emissions by tonnes of carbon monoxide (CO), volatile organic compounds (VOC) and nitrogen oxides (NOx) over the course of the year.

- Reduction of acoustic pollution.

- Planting and greenery along the route of UMS which is a big health benefit.

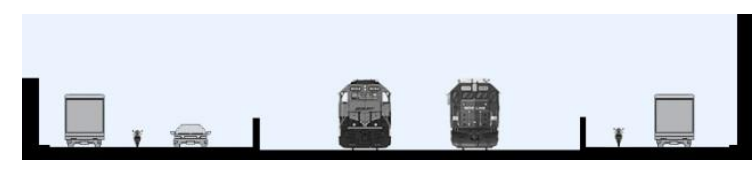

Figure 4.2: Existing IUCRS - Cross Section

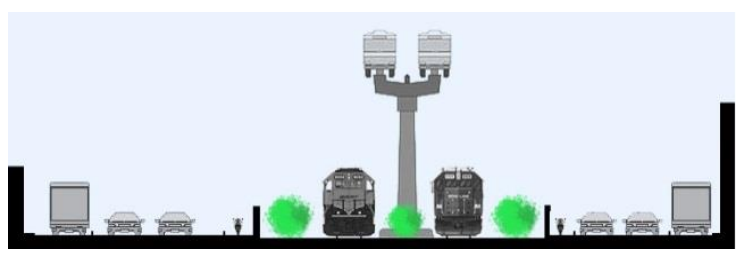

Figure 4.3: Proposed UMS - Cross Section
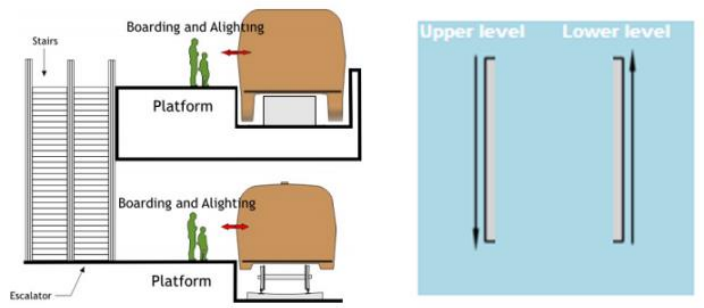

Figure 4.4: Proposed UMS Platform - Cross Section

Figure 4.2 refers to a cross-section for the existing IUCRS indicating the distribution of lanes of several transit modes and its width the cross the road.

Figure 4.3 refers to the proposed development of the past cross-section including the UMS and the rearrangement of the lanes after the development. 
Figure 4.4 explains the distribution of platforms in presence of the recent IUCRS and the new implemented UMS.

\subsection{Transport Questionnaire}

This Questionnaire presents many ideas for the promotion of Transportation. From the reasons, why it is vital and necessary, to how to design for it, support it and promote it, the guidelines given are intended to help the passenger makes transportation an integral part of Urban development.

The questionnaire is addressing 100 passengers of the recent railway system under process, it goes into 12 parts.

Part 1: General Questions:

- Preferring Private cars or Urban Public Transport?

- Does Urban Public Transport cause pollution and congestion?

- Does Urban Public Transport help in link passengers' community?

Part 2: Boarding/Getting off:

- How to buy train's ticket?

- What is train travel trip purpose?

- How many times travel by train?

- How to reach the train station?

Part 3: Accessibility:

- Ability to pick up the train in case of intending to ride?

- Ease of boarding the train?

Part 4: Timeliness:

- The timing of the train is appropriate?

- The train comes on time (while keeping a schedule)?

- Travel time due to travel distance, is long or short?

Part 5: Cleanliness:

- The degree of train station cleanliness?

- The degree of the train (seats, floors and windows) cleanliness?

Part 6: Information:

- Availability of schedule information at the train station?

- Easy to understand visual banners (clear and useful)?

- Easy to understand audio ads on the train platform?

- The presence of staff to serve people with special needs and invalids?

Part 7: Comfort:

- Comfort at the train station (shelter and seating)?
- Availability of seats on the train?

- Feeling the comfort of seats on the train?

- The degree of temperature level on the train?

- Feeling full comfort throughout the trip?

Part 8: Ticketing:

- Easy access to information on places of purchase and tariff of tickets?

- Easy to buy a ticket?

- Currently, the applicable tariff is appropriate?

Part 9: Safety:

- Feeling safe at the train station?

- Feeling safe on the move of the train?

Part 10: Easiness:

- Availability of private parking near the train station?

- Ease of passenger transport by intermediate means near the train station?

- Easy communication with other public transport?

Part 11: The proposed new (sustainable) mode of transport-UMS:

- Agree with whether (the people/government) wants to develop a mean of transportation that is lifted from the ground (which reduces the internal transport of the city, saves time, improves the quality of the environment and reduces travel fatigue), but on the other hand, it needs a high budget?

- Should the government take the opinion of the people before taking this step?

- Should be there a survey every three years to look for the positive and negative effects of the proposed new (sustainable) transport mechanism?

- Agree with commercial investments, bus stations, parking places under each station and green spaces along the way?

- Agree to raise tariffs in return for improving service by introducing sustainable urban transport?

Part 12: Personal Information of the passenger:

- Male/Female?

- Age?

- Job?

- Alexandrian or not?

\subsection{Transport Questionnaire Results}

This Questionaire was applied upon samples of 100 passengers using the line under study between Abuqir Station and Sidi Gaber Station.

It was applied to passengers for both males and females covering the age range between 16 years old up to 60 years old. The samples covered passengers of all sorts: clerks, students, 
housewives, and retirees. It was noticed that $92 \%$ of the users were Alexandrians.

Along the Questionaire we can conclude the following notes:

$>$ The majority of the passengers are not satisfied with the recent the Railway service ie:

- There is no fixed timetable for the trains, random timing is noticeable for almost $77 \%$ of the sample.

- The cleanliness of both the train and the stations is not acceptable for almost $85 \%$ of the sample (ranging from Very bad to Fair).

- The comfort of the passengers at the station and on the board of train is not acceptable for almost $60 \%$ of the sample.

- The safety of the station and on board is not acceptable to almost $75 \%$ of the sample.

- The lack of Garage adjacent to most of the stations is noticeable and there is a complaint of this lack for almost $60 \%$ of the sample.

- Shortage of personnel responsible for the aid of disables is a common complaint about a majority of $88 \%$.

- Air and sound pollution was also an issue of complaint about majority $76 \%$ of the sample.

$>$ On the other hand, it was found that the line is helpful and preferable for transportation for the majority of almost $71 \%$ of the sample (most of them are students and clerks who use the line daily or weekly for a majority of almost 55\% and $44 \%$ for fewer rates than that) because it is a single mean of transportation running in specific route without sharing with other means.

$>$ There were some advantages that majority appreciate, ie:

- The tariff is reasonable.(Cheap)

- They can reach the station through several intermediate means near the train station ( Tuktuk, bus, taxi, tram, and minibus ) or even walk.

In a spot of so mentioned results a proposal to implement a new mode of transit UMS was submitted to the passengers to develop the recent service and overcoming the disadvantages and suffers from it.

The following points were gained:

- Approval of a majority of $93 \%$ of the sample to implement the UMS project.

- Approval of a majority of $73 \%$ of the sample for the government to proceed as long as investments are available.

- Approval to increase the tariff as long as they will gain a better sustainable service.

- Approval for the commercial investments, bus stations, parking places under each station and green spaces along the way which will create an integrated regions along the route.

\section{Conclusion}

With the development towards monorail and its advantages over conventional rail system, the monorail is the technology of the future. The monorail will be the optimum solution for a new efficient, sustainable and environmentally friendly transit mode via rapid construction and operation, replacing the conventional systems.

The operation of monorail will be saving the precious fuel, land, time and atmosphere. Many types of research are under process to optimise monorail to be more advanced and environmentally friendly.

With both the study done by the researcher and the questionnaire among the passengers of the recent Urban Public Transport Systems, almost all passengers agree upon the implementation of the Straddle UMS and the development of the stations to achieve the optimum environmental and atheistic Urban Mode of Transit in Alexandria City.

\section{References}

Desmond, G. (2015). The Effectiveness of Park and Ride as a Strategy for Sustainability, a Case Study of the Northern Dart Corridor.

Erdemir, S. M. (n.d.). Why Travel by Train? Retrieved from USA Today: http://traveltips.usatoday.com/travel-train9946.html

Joodi, P., Momeni, M., Kooshki, H. S., \& Azizi, H. (2011). Impact Assessment of Sustainable Public Transportation System on Quality of Life in Tehran.

Wang, B. (2003). Constructability Analysis of Monorail Project.

(2013). Retrieved from Public Transport Victoria: http://ptv.vic.gov.au/about-ptv/mediacentre/student-media-enquiries/benefitsof-public-transport/

Ahkâm. (2016). City bus. Retrieved from http://www.freeiconspng.com/img/40043

Black, W. (2010). Sustainable Transportation: Problems and solutions. Guilford Press. 
Ishikawa, K., Ohazama, A., Sora, H., \& Sekitani, T. (1999). Straddle-type Monorail as a Leading Urban Transport System for the 21st Century. Hitachi Review Vol. 48, pp. 149-152.

(n.d.). Japan Monorail Association Guide.

Kennedy, R. R. (n.d.). Considering Monorail Rapid Transit for North American Cities.

Kuwabara, T., Hiraishi, M., Goda, K., Okamoto, S., Ito, A., \& Sugita, Y. (2001). New Solution for Urban Traffic: Small-type Monorail System. Hitachi Review Vol. 50, pp. 139143.

Lynn, P. R. (n.d.). Advantages \& Disadvantages of Train Travel. Retrieved from USA Today: http://traveltips.usatoday.com/advantagesdisadvantages-train-travel-39897.html

Rietveld, P., \& Stough, R. (2010). Barriers to Sustainable Transport. Spon Press.

Tarighi, A. (2011). Multi-Criteria Feasbility Assessment of the Monorail Transportation System in Metu Campus.

Tram. (2016). Retrieved from https://www.turbosquid.com/3dmodels/streetcar-tatra-t3-tram-3d$\max / 789383$

\section{UNITED NATIONS, BUREAU}

INTERNATIONAL DES

EXPOSITIONS, \& CITY OF

SHANGHAI. (2010). Sustaiable Urban Transport. In Shanghai Manual - A Guide for Sustainable Urban Development in the 21st Century.

www.waterkingdom.in. (n.d.). Trains. Retrieved from http://www.waterkingdom.in/img/Train.pn $\mathrm{g}$ 